\title{
Managing the hinterland beyond: Two ideal-type strategies of economic development for small island territories
}

\author{
Godfrey Baldacchino \\ University of Prince Edward Island, Charlottetown, Canada. \\ Email: gbaldacchino@upei.ca
}

\begin{abstract}
Rarely does one come across critical analysis which looks at islands as the strategic and candid promoters of a role as political and economic usufructuaries over external resources. This paper is premised on the proposition that a small territory is especially obliged to use extra-territorial resources as its hinterland for economic success. Such resources extend over a whole range of goods and services and include access to investment, welfare, security, stable currency, international relations, specialised labour power, transfers, markets and higher education. The MIRAB syndrome is one way of articulating this condition. This paper proposes a second cluster of features that are, or can be, deployed by small territories in a manner somewhat different from MIRAB; this second cluster has a more proactive policy orientation and a disposition towards carving out procedural and jurisdictional powers. It is thus proposed to consider a small territory's engagement with the external hinterland as a position on a sliding scale, a strategic mix of options located between two distinct development trajectories, of which MIRAB is one and the PROFIT model the other.
\end{abstract}

Keywords: economic development, hinterland, MIRAB, PROFIT syndrome, small island

Writing in 1984, economic historian William Green regarded population density as a principal factor determining the nature of labour relations in the post-emancipation Caribbean. High population density on a small and insular land area, he argued, led to the non-availability of plots of land for private use by emancipated slaves; the latter thus had little choice but to seek employment on plantations. Moreover, the colonial presence was 'sometimes intimate, and always weighty' (Green, 1984: 114). These conditions were not conducive to the development of an independent peasantry. Barbados presented the most extreme example:

[It] had almost no forest: it was fully cultivated, rifled with roads, and bestrewn with villages, stone churches, windmills and factories.

Along with other island territories such as St Kitts or Antigua, in Barbados:

... there was no sense whatever of the vast primeval forest that extended beyond the tiny squalid settlement at Belize and intruded deeply upon the social psyche of its inhabitants. (Green, 1984)

Of course, population density, much like smallness or insularity, does not cause anything. It is a condition, not an attribute. There may be, however, something going on here that is worth reflecting on. Does the existence of a 'vast primeval forest' impact on the social psyche of a population? Would the absence of any such forest impact as well? And if so how?

The comparative study of small islands confronts us with observations similar to Green's. Discarding the specific nuances of personalities, history, climate, time and space, these observations suggest that the availability, or absence, of such a feature as a forest, or some other immense domestic natural endowment, can have a critical and determining effect on human behaviour generally, and on economic growth and development strategy specifically. 


\section{Effects of absence of a local hinterland}

Various arguments drawn from a number of social science disciplines suggest that the absence of a natural domestic endowment is an intervening variable in the development of a territory.

Helen Hintjens, a Réunion-born political scientist, observes this much in relation to France's erstwhile colonies in the Indian Ocean. These islands became inhabited only at the time of the European Age of Discovery. Thus, the settlers were the natives in the Mascaregnes, and there was hardly any tension with indigeneity. With relatively small land areas and high population densities, the locals found no objection, and no alternative, to remaining culturally incorporated within the metropolitan regime. They had 'virtually no physical or cultural hinterland to retreat to' (Hintjens, 1991: 38). Assimilation (after Miles, 1986: 198-206) was well nigh total and complete. In spite of its limited administrative presence in the region, the cultural hegemony of France in the broad Indian Ocean has remained vibrant (e.g. Houbert, 1986).

Australia-based demographers Caldwell, Harrison and Quiggin, back in 1980, had already come to the conclusion that insular microstates are more 'westernised' (Caldwel et al., 1980: 960). 'They were part of the European maritime system at a time when the West did not have the economic strength to penetrate continental areas to the same extent' (Caldwel et al., 1980: 953). Their 'westernisation' is measurable: a higher propensity to migrate to developed countries; in the late 1970 's, $85 \%$ were predominantly Christian; $91 \%$ had an official European language; $87 \%$ had a majority of the population able to speak either a European or a Creole language (Caldwel et al., 1980: 954).

For British economist Paul Streeten, the absence of a local rural hinterland has pivotal significance to economic development. It exempts a territory from a dependence on 'the slow-coach of agriculture' (Streeten, 1993: 199). In the case of small, densely populated territories starved of land - such as the citystates of Singapore, Hong Kong, Bermuda and Malta - industrialisation or tertiarisation have been the inevitable growth poles, obliging a quick shift of mind-frame towards export promotion and the penetration of export markets.
Absence of a hinterland also inhibits the formation of a land-owning peasantry or plantocracy which can become a formidable lobby in domestic and regional politics, seeking protection from cheaper imports and contributing to higher costs of food items to consumers.

A forest, jungle, desert, swamp or a mountain range, is often seen as (i) an outback, far from the centres of habitation and urbanisation; (ii) a place of refuge, escape, or of a 'fall back', defensive or regrouping position in times of war or pursuit; as well as (iii) a reservoir, fount or stock of diverse reinvigorating supplies and resources - physical ones such as agricultural produce, land or lumber; but also less tangible assets such as ancestral culture, spiritual refreshment, health, composure, inspiration or crude energy.

I shall, in this paper, be referring to such places, real or imaginary, as hinterlands. I find the word apt because it synthesises all three senses of outlyingness, refuge and potential. It is the term already used by Hintjens and Streeten in their assessment of the development trajectories of small island territories. It is a term used readily in human geography to represent an outlying service centre feeding a metropolitan area, often acting as its 'living space' (Cracknell, 1967): it is a relationship in which demand originates in one location but is satisfied in another (Greer and Wall, 1982: 227). The absence of an interior, a local hinterland or a local terrestrial core area is a small island characteristic recognised also by the United Nations (Griffith and Inniss, 1992). ${ }^{1}$ It would be very difficult to imagine Robinson Crusoe without the opportunity to make thirteen trips to his wrecked ship (Hymer, 1971: 17).

The concept of a hinterland also connects easily with other, perhaps more current, terms. Take that of a 'footprint', often applied to ecology (e.g. Gössling et al., 2002): it appears that, ceteris paribus, the smaller the territory and the higher the population density of its inhabitants, the more likely is it that its footprint extends beyond its shores. Extending the argument to the more familiar, although fuzzier, concept of 'sustainability', one could contend that, as far as small islands are concerned, 'speaking of sustainable development is a contradictionin-terms' (Connell, 1988a; Bertram, 1993; Baldacchino, 2004: 6) because the small local- 
insular would not survive without drawing in resources and assets from, while flushing out excesses and undesirables to, a hinterland beyond.

Turning to the vulnerability thesis (Briguglio, 1995), the model is faulty precisely for assuming closed, autonomous systems: adopting a territorial, closed system or statist perspective leads one to conclude that many such states survive only on the basis of 'artificial props' (Briguglio, 1995: 1622). Parasitism remains a bad word (Baldacchino, 1993) and is looked upon with 'scorn' (Poirine, 1998: 65). Development qualifies as non-sustainable because it is not underpinned by productive activity within the territorial boundaries of the island economy (Bertram, 1993: 248). Rather, islands, smaller islands in particular, must exhibit a generous degree of openness and integration with the outside world in order to survive (Bertram and Watters, 1986: 52; Baldacchino, 2000). So, by way of example, the handling of the aftermath to the Montserrat volcanic eruptions in the 1990s would have been a very different story were the small colony a closed system; not benefitting from external support, and particularly without the intervention of the UK.

It therefore does appear that a crucial distinction in the evolution of societies and economies has to do with the perceived availability or otherwise of a local hinterland. I have included the word 'perceived' because, where human beings are concerned, there is no hard-and-fast direct relationship between physical conditions and human behaviour. It was thus easier for Singapore to develop an export orientation psychologically since it had prospered with Malaysia as its hinterland until independence in 1965. Easter Island/Rapa Nui has become the classic example of a now extinct community which perhaps ended up consuming itself because, in the face of obvious constraints on finite material resources, it failed to recognise the option, or to develop the required technology, to expand beyond its shores. Although extreme population densities (low - as in Pitcairn, or high - as in Singapore) could endanger people's lives and access to resources, it is also clear that many societies survive fairly well in what may be seen by others as simply unbearable extreme circumstances. ${ }^{2}$

\section{Politico-economic behaviour of small territories}

These arguments, of course, are not new. They have been taken forward and elaborated upon to explain the political and economic behaviour of small territories.

Thus, Caldwell et al. state that: 'on the whole, they [that is, island microstates] retained colonial links longer' (Caldwell et al., 1980: 960). This is also affirmed by Doumenge (1989: 51). Few, if any, struggled for independence; most have waged intense diplomatic struggles to maintain or extend benign colonial links with their overseas hinterland; at times going so far as to press for integration, the very antithesis of sovereignty (Guillebaud, 1976; Winchester, 1985; Baldacchino, 1997: 176177). An intriguing mathematical relationship presents itself in political geography, whereby, in the post-World War II period, the larger, mainland colonies struggled and obtained independence first - with the largest extant (mainland) colony India being the first to do so traumatically in 1947. Meanwhile, the smaller, mainly island, colonies have either obtained political independence last, or else continue to stubbornly refuse to shift gear from their current, non-sovereign status. There are at least 41 examples of the latter, and the numbers are not falling (Royle, 1989: 108). Predictions that such places as Montserrat, Aruba, New Caledonia, Greenland and the French overseas departments would become independent by the early 1990s have been proved incorrect (Sutton, 1987: 5).

In the realm of economics, Kakazu (1994) has suggested that such small territories be looked upon as harbouring rentier economies, offering their strategic location, investment potential, fishing rights, tax differentials or tourism products to attract 'rents' based on productive value added generated (in hinterlands) overseas. Such policies, where successful, have tended to see a shift from productive status to rentier status, and even stronger/deeper integration with metropolitan powers and their economic cycles. When accompanied by the abandonment of what little commercial agriculture or fishing may have been possible, the shift becomes one 'from subsistence toward subsidy' (Connell, 1991: 271). 
In this case, domestic industrialisation is not induced by the winding down of the primary sector, but rather summarily skipped (Miles, 1986: 158; Baldacchino, 1998). Small territories find themselves in the post-industrial era, without the scars and polluting effects of an industrial past, enjoying high levels of affluence and consumption predicated on an unorthodox, possibly shifting, combination of resources. These include remittances from 'transnational corporations of kin' (Marcus, 1981); bilateral and multilateral aid; public sector employment and contracts; philately, conch shells, international dial-up codes and Internet domain names/sites (Prasad, 2004).

The common basis to the above arguments is that they suggest novel departures from more standard conceptualisations of development where the engagement with the hinterland falls under the rubric of less significant, marginal affairs. The stark truth of various small, mainly island, jurisdictions today is that they thrive mainly on such external relations.

The MIRAB model (Bertram and Watters, $1985,1986)$ is today arguably the most popular acronym for explaining this condition although its popularity may be less widespread than is sometimes supposed. ${ }^{3}$ The key hypothesis states that: '[T]here is today a class of economies and societies in which the combined effect of migration, remittances, aid and bureaucracy... determines [rather than supports] the evolution of the system' (Bertram and Watters, 1985: 497; emphasis in original). The notion of 'autonomous economic growth' in specific contexts is simply 'false' (Watters, 1987: 33). In spite of a number of suggested alterations (MIRAGE by H.C. Brookfield, 1986, quoted in Connell, 1988a: 81; MURAB by Munro, 1990; MIRTAB by Ogden, 1993; TouRAB by Guthunz and Von Krosigk, 1996), the MIRAB concept remains steadfast and, perhaps, has even assumed of late the stature of a self-fulfilling prophecy, especially in the South Pacific. It is not only a welfare-maximising strategy in line with the theory of competitive advantage (Poirine, 1998: 91); it now may, or may be seen to, legitimise, justify and lock-in such an economic development strategy in the long term (Treadgold, 1999). As long as sources of revenue remain secure, and as long as the shifting fortunes of any such 'external' source is adequately compensated for by any other similar 'external' source, existing or new, then that is, in practice, all that really matters - an unorthodox but effective sense of sustainability and entrepreneurship (Bertram and Watters, 1985: 512; Bertram, 1993: 257).

Is this a case of plus ça change, plus c'est la même chose? The MIRAB cluster reveals itself as a standard 'development' tactic to peripheral regions and territories the world over. In cases where there are metropolitan cores and stagnant peripheries - and where aren't there? - the MIRAB cluster of features constitutes the classic response to assuage the ailments of those on the edge, particularly if accompanied by a dominant ideology of professed redistribution and equalisation - that is, unless the central power 'is prepared to see living standards slide' (Bertram and Watters, 1985: 513). After all, the standard measures used by the core to support the periphery include an element of workfare (read bureaucracy within MIRAB) and transfer payments (read aid within MIRAB); meanwhile, migration, internal this time, is also likely from the periphery to the centre, as people - particularly the young, the skilled, the educated, the ambitious - search for work and a still better education, occasionally visiting relatives back home or sending them gifts in cash/kind every so often (read migration in MIRAB). The novelty of MIRAB, other than the fancy yet meaningless acronym, lies in identifying uncannily similar patterns operating between states, and not just within them.

The MIRAB allure is quite remarkable. It seems that, having named the beast of the apocalypse, there is now no restraining its triumphant imperial project. When it was conceived, Bertram and Watters applied the syndrome primarily to just five small, Pacific microterritories, two of which were recently independent states (Kiribati, Tuvalu); and the rest semi-autonomous sub-national jurisdictions (Cook Islands, Niue, Tokelau). In a MIRAB + 12 paper, (Bertram, 1999), Western Samoa (now Samoa), Tonga, French Polynesia, Federated States of Micronesia, other small US-associated Pacific Territories and Rapa Nui, as well as the outlying islands of so-called 'non-MIRAB' island states, like Fiji, Papua New Guinea and Solomons, were added to the pioneering five, or noted to have been added by other researchers. By 1998, the US 
Virgin Islands, Guadeloupe, Martinique, Saint Helena, St Pierre et Miquelon and Mayotte are added to the list from beyond the Pacific basin (Poirine, 1998). McElroy and Morris (2002) identify and confirm four African island states as MIRABs: Cape Verde, Comoros, Mayotte, São Tomé and Principe. We have been told that 'all SPINs [South Pacific Island Nations] match to a greater or lesser degree the model of rentdependent MIRAB' (Fleming, 2002: 6). Connell (1991: 252, 270) had argued that the model is applicable, to a greater or lesser extent, to most small island countries, because most of these have moved 'from subsistence to subsidy' (Connell, 1991). It is not just the economic system described, but the model itself, which appears to be durable and persistent.

Yet, is this really the case? Has MIRAB unwittingly become a convenient development paradigm that dismisses alternatives? If MIRAB has real explanatory value, this does not necessarily mean that it is the only measure of small island development. There may be alternative small island development syndromes, as distinct from conventional resource-based development models as MIRAB, at work among small island territories today. There may be, in other words, non-MIRAB, pre-MIRAB and/or post-MIRAB strategies for engaging with the hinterland beyond. Any such different combination of factors is, like MIRAB, as much at home in the realm of sub-national as of national/sovereign island jurisdictions. To appreciate this alternative, the reasons why many, mainly island, small territories have not opted for political sovereignty merit being reviewed. The dynamics between the semi-autonomous territory and the larger, sovereign state (and often former colonial power) are uncannily similar to the purported advantages of a MIRAB strategy.

McElroy and Mahoney (1999) explain how political affiliation continues to grant substantial economic advantages to small, non-sovereign, island units. These benefits include: free trade with, and export preference from, the parent country; social welfare assistance; ready access to external capital through special tax concessions; availability of external labour markets through migration; aid-financed infrastructure and communications; higher quality health and educational systems; natural disaster relief; and provision of costly external defence. Autonomy without sovereignty also does not hinder the development of flourishing tourism economies, and may actually facilitate them because of easier terms of access and security. Most of these special conditions have emerged in the context of a history of a relatively benign colonial relationship - typically one which was dominated by strategic rather than economically exploitative interests.

Meanwhile, a fair dose of jurisdictional clout inhibits any concerted drive for political independence. Many small islands, because they are islands, enjoy some degree of administrative autonomy (Baldacchino, 2000), also as an unwitting benefit of colonialism. This same feature lies behind the credentials for, and eventual transition of small islands to, statehood. Furthermore, because they are also small, sparsely populated and/or somewhat isolated or unique, such island jurisdictions usually manage to extract some special advantages from their respective metropole. Although they may have refrained from sovereignty, they would nevertheless, jurisdictionally or constitutionally, typically enjoy more discretionary powers than any similarly sized or even larger chunks of the 'mainland' (Poirine, 1998). Thus, the independence candle for islands may appear snuffed, at least for the moment, and in spite of any nationalist aspirations (e.g. Trompf, 1993: xxv). Meanwhile, the current status of autonomy without sovereignty is seen as the best of both worlds providing many of the benefits associated with political sovereignty while delegating responsibilities, enjoying security and reaping the material benefits of remaining in association with a larger, and typically richer, albeit often reluctant, patron.

Smallness of population and/or land area, isolation and islandness can act in concert to fuel a distinctive territorial politics while safeguarding and differentiating it from external 'intervention'. These departures are not exceptional: it would be wiser to see them as examples of the carving out of political niches where geography facilitates, while at the same time circumscribes, the territorial scope of any achieved/ granted powers and privileges. More than that, these are also examples of alterations in geoeconomic space. As economic power is transferred 'upward, downward and outward from nation states' (Courchene, 1995: 3), jurisdiction 
is increasingly recognised as a very useful driver and primer for such purposes. It becomes the 'catapult' which allows the entertaining of differentiation within the local state, as well as of developing an international (or better, an ultranational) presence on the global or regional stage (e.g. McKercher, 2000).

The benefits resulting from the extraction and deployment of jurisdictional power call for increased recognition (Baldacchino and Milne, 2000). They usually translate into a larger localisation of control over economic and political decisions. Of course, the apex of jurisdictional powers - powers far greater in relation to the small size of a land mass or resident population - has been achieved and assiduously cultivated especially by sovereign small, often island states: the fisheries policy in Iceland; banking policy in Luxembourg and Liechtenstein; sustainable tourism policy in the Maldives and the Seychelles; and a globally competitive textile and garments industry in Mauritius. But the political economy of success is even clearer among non-sovereign island territories. Discretion over taxation and offshore finance has been behind the success of such territories as Madeira, Bermuda, British Virgin Islands, Turks and Caicos, the Isle of Man and the Channel Islands; discretion over language policy, shipping registration and property ownership lie at the heart of the Åland Islands autonomy from Finland; and some jurisdictional autonomy of varying degrees is enjoyed by island provinces of larger states, in spite of the usually small relative size of land and population (Barbuda, Gozo, Hong Kong, Kinmen, Nevis, Zanzibar, the status apparte of Aruba, the departements d'outre mer of France, French Polynesia, Labuan, New Caledonia, Svalbard, Hainan, Galapagos, Rapa Nui, Tasmania, the Balearics, the Canaries, the Azores ....).

What we have here is a combination of freeriding by the smaller, island party in the context of (at times deliberate) oversight by the larger, metropolitan party, crafting in the outcome some kind of regulatory legitimacy, while the island faction never completely relinquishes the potential resort to the metropole, if and when dire straits so determine or suggest (such as budgetary shortfalls; environmental disasters; over-population; labour surpluses or shortages). In this way, they avoid that chronic vulnerability which results from systemic closure and which is supposed to plague small, island territories most of all (Briguglio, 1995).

The key difference between these strategies and those falling within the MIRAB rubric is that the former are based on jurisdictional discretion, meaning the ability to adapt local laws and regulations to suit the requirements of the microinsular economy, even if these laws and regulations differ from those of the metropole in which the small territory finds itself politically incorporated. Neither (out)migration, remittances, aid nor bureaucracy need depend on differential constitutionalism. Of course, a critical question to ask is whether any such departures from the norm are actually indicators of autonomy, or merely manipulations driven and controlled by the central state to its own net advantage, often without any consultation or power-sharing arrangements with the island locals. ${ }^{4}$

However, and following critical observation, utilising jurisdiction as a resource is one way of compensating for the dearth of conventional economic assets (Baldacchino and Milne, 2000). It is another shrewd survival strategy based on a specific form of international relations: deploying a flexible and creative diplomacy, adopting free riding (in such matters as international relations, defence and security as well as currency issues), slipping free or through the nets of regulation and/or cultivating special, ultra-national, economic linkages. All these measures constitute a skill repertoire that the small and powerless deploy and, being small, often get away with. They may, in the process, also be providing useful regulatory escape routes for their metropolitan patrons, as perhaps best illustrated by offshore finance regimes. Such is the character of the dynamics of unequal dyads, or unequal federalist arrangements (Watts, 2000).

Sub-national jurisdictions may be tempted in the near future to carve out policy discretion on a specific number of areas, and economic relationships with a specific clutch of attractive metropoles, in their favour. As the nation state, already in itself a mythical construction of modernity, finds itself too big as well as too small to address key political problems (Bell, 1987), the pressures for internal devolution and internal federalism in the contemporary 'fragmegrative' space (Rosenau, 2003) will increase, 
just as the incentive for supra- and ultra-national agreements with other neighbouring states or components thereof will also. It is likely that, as in the case of Malta and Mauritius 40 years ago, political sovereignty as a fully-fledged state will only be seriously entertained, or threatened with some degree of bluff, if what is considered a better deal by the smaller player is absolutely unacceptable to the larger. ${ }^{5}$ The same political contest is bound to occur at a supra-national and regional level, as nations jockey to maintain policy autonomy while recognising that 'pooled sovereignty' is the only way forward to render such bodies as the European Union (EU) even more effective. The EU and the euro exist in the first place as the outcome of such a sober assessment. 'Government' (meaning decisionmaking by elected representatives) thus gives way irrevocably to 'governance', meaning decision-making by a plurality of networked partnerships (Rosenau, 2003).

A second observation concerns the financial dimensions of development. Conventional economic statistics rank countries according to gross national/domestic product or purchasing power parity standards. Wealth is often defined in such terms as GNP/GDP/PPS per capita. Small, often island, territories are doing exceptionally well on these counts. In their powerful critique of the alleged structural vulnerability of many small (often island) territories, Armstrong and Read (2002) conclude that smaller jurisdictions actually perform economically better than larger states. Comparative research has shown that, on average, non-sovereign island territories tend to be richer per capita than sovereign ones (Poirine, 1998; Bertram, 2004). The citizens of French Polynesia, Aruba, Bermuda and Iceland are counted among the world's top ten richest people (The Economist, 2003). That the first three of the above four territories are nonsovereign states is insightful; but, moreover, only the first can be considered a MIRAB-like economy. Stopping short of full independence, while negotiating access to spoils within a larger jurisdictional framework, appears to pay off. Yet, is jurisdictional clout only there for the purpose of extracting more largesse from the core?

Alan Fox (1969), a British industrial relations scholar, divides the spoils of the production relationship between 'manager' and 'managed' into two categories. He called the first 'substan- tive rewards' (meaning tangible results like wages, hours of work or allowances) and the second 'procedural rewards' (meaning processual details like who gets to decide on a promotion, or how workers are dismissed). It appears that MIRAB emphasises the substantive gains - the 'what' - to a small economy (at both macro and micro levels), but dismisses or downplays the procedural ones - the 'how'. A second approach may treat the procedural goals as the priority, with the substantive results coming in eventually 'downstream' as it were, as a consequence of the shrewd use of policy capacity.

\section{Creative political economy: Five capacities}

Armstrong and Read (1998: 13) have argued that many very small states - most of which are island or archipelagic territories - have managed to compensate effectively for their small size by ensuring a high quality of 'endogenous policy formulation and implementation'. They also contend that 'further investigation of the policy stance of successful microstates, particularly in the sphere of international political economy, is likely to be fruitful' (Armstrong and Read 1998; my emphasis). Earlier, Katzenstein (1985) had made similar remarks in relation to small European states. Such insightful observations can apply equally well to sub-national considerations, and not just to international relations.

Island-based and island-biased literature suggests five policy areas as being most likely to fall within the remit of self-rule; as being looked upon by many sub-national island authorities/ spokespersons as policy concerns which they would most prefer to have under local control; and as being critical ingredients in shaping economic prosperity (e.g. Milne, 2000). Contestation over 'who does what' in these policy areas has also been typically tense, especially in federal political systems, and may in itself lead to demands for more self-rule, its withdrawal or its renegotiation between the parties concerned. These powers are, like the MIRAB quartet, premised on effective governance; however, unlike the MIRAB quartet, they depend much more on the proactive nurturing of specific, local, jurisdictional capacities or local powers. They comprise the management of external relations but, unlike MIRAB, this is done '... by means of 
domestic policies and governing institutions' (Warrington, 1998: 101). Each of these selected five policy areas is briefly elaborated upon below.

Powers over finance, mainly banking, insurance and taxation

Most offshore finance centres are located on small island territories: out of 54 jurisdictions listed on a 'low tax' website, 27 are islands or archipelagos. ${ }^{6}$ This is because the latter habitually involve few significant domestic transactions, draw in 'rent'-based surpluses from elsewhere and are therefore not unduly troubled by low tax policies (Baldacchino and Fabri, 1999: 141; Kakazu, 1994). Hampton and Abbott (1999b: 7) argue that locating offshore finance centres on small islands helps to place the industry more closely within government approval and thus increase investor confidence. Smallness and insularity may however precipitate a 'capture of the local state' by international financial capital, such as international banks and large accountancy firms (Christensen and Hampton, 1999) as well as not-so-respectable operations (Royle, 2001: 180). The Group of Seven (G7) Task Force's published blacklist of 15 territories where money laundering was allegedly taking place included 10 island locations (G7 Financial Action Task Force on Money-Laundering, 2000). Successful finance centres in small economies also tend to 'crowd out' pre-existing industries (such as agriculture or small-scale manufacturing), leading to increases in the price of property and skilled labour. This is the condition of such island territories as the Channel Islands (Hampton, 1994) and Madeira (Milne, 2000: 17-18).

Baldacchino and Milne (2000: 232) consider the power to tax, and tax differently, as critical to economic prosperity. An exceedingly low tax environment - via low corporate taxes and business rates, generous capital allowances, absence of capital gains tax, wealth tax, capital transfer tax, inheritance tax, death or estate duties, along with low personal income tax rates (15-20\%) - goes a long way towards attracting both manufacturing and service industries (Baldacchino and Milne, 2000). Such a clutch of fiscal powers, with the backdrop backing of a large reliable 'patron' state, under- lies the success of the Isle of Man (McKercher, 2000) or Labuan in Malaysia (Abbott, 2000).

Locating international (offshore) finance centres, banks and insurance companies on (low/ no-tax) islands as enclaves of larger states allows for a reaping of the benefits of the industry while containing the associated costs.

\section{Powers over environmental policy, particularly} natural resources

The management of specific local resources desired by the central state - oil, gas, mineral deposits, fishing zones, strategic bases, tourism potential, or sheer political loyalty - can be, and has been, used as leverage for extracting some degree of policy autonomy. ${ }^{7}$

The Canadian Provinces of Alberta, Newfoundland \& Labrador and British Columbia, as well as the Shetland Islands in the UK, have successfully negotiated some local powers from the central state over critical dimensions of their economy, largely in relation to jurisdiction over oil, gas and other subsoil resources (Baldacchino and Milne, 2000: 234; Cullen, 1990; Blackadder, 1998). The same, however, cannot be said about the management of the Newfoundland fishing stocks (Baldacchino and Milne, 2000: 233). North Sea oil and gas has also led to some renegotiation of the power balance between the Faroe Islands and Denmark (Olafsson, 2000) and between the Shetland Islands and the UK (Blackadder, 1998). Svalbard (Spitzbergen) is special with its bilateral treaty provisions over mining access reached between Norway and USSR/Russia. ${ }^{8}$ Sakhalin Island, with its prized oil resources, has its own governor; yet it is not a Russian federal district.

Other islands have extended their economic zones over tracts of sea many times larger than their own land mass (Falklands). Still other islands - like Hainan (China) or Batam (Indonesia) - have benefited economically by being designated special economic zones (see Chongyi and Goodman, 1997; Royle, 1997, respectively). What needs to be researched is whether such changes have been accompanied by a measure of power transfer from core to periphery.

Meanwhile, the contribution of islands to cultural, environmental and biological diversity is 
proportionately much greater than the size of their territories or populations (e.g. Young, 1999: 253). Sixteen sites from 13 different island regions in Europe have been included by UNESCO on its World Heritage list. ${ }^{9}$ Islands which in toto are also World Heritage Sites like Rapa Nui or Galapagos - are run differently from the 'normal', mainland provinces of Chile and Ecuador, respectively.

Powers over access, particularly in relation to air and sea transportation

Transportation is often a triple problem of choice, time and price for islanders. Generally speaking, islanders know that transportation options and frequencies decrease and verge towards monopoly provision, transit times increase and prices rise with increasing distance from mainland areas, and with decreasing size of a specific island's population (Conference of Peripheral Maritime Regions, 2002: 25-26). Archipelagic islands compound these issues even further (Hamilton-Jones, 1992; Bayliss-Smith et al., 1988). Difficulties with transportation affect a whole range of issues, including the viability of a tourism industry, a manufacturing export strategy, absence of economies of scale, as well as limitations to emergency off-island health care (Baldacchino and Milne, 2000: 234). Distance means high cost for the transport of goods, services and people, and effectively reduces access to the metropole, even for those overseas areas where residents are citizens of a European mother country (Connell and Aldrich, 1992: 33). An analysis of the population history of the Irish Islands suggests a clear relationship between levels of access and population decline (Royle and Scott, 1996). Island transportation is often in the hands of 'governments' (Royle, 2001: 113), but which, and at which level, in a federal arrangement? The Aland Islands' control over its shipping registry and the safeguarding of duty-free transactions on Åland ships flying the Åland flag have been crucial to the territory's economy (Lindström, 2000). In contrast, Niue's dependence on a weekly Air Nauru service led to a belowcapacity operation for its fledgling tourism industry when that service was discontinued for over two years (Milne, 1992: 568).

\section{Powers over free movement of persons}

Sub-national island jurisdictions usually come along with small populations and a small land area. Given that smallness increases the disposition towards all round volatility (e.g. Dommen, 1980; Easterly and Kraay, 2000), the threats of depopulation or overpopulation loom larger, as do the resulting impacts on labour supply and demand, and on housing stock surplus or shortages. Archipelagic island territories must also contend with the additional dynamics of internal migration and urbanisation. Acute emigration (and, more infrequently immigration) are the safety valves readily available in response to all-too-frequent demographic, real estate or employment imbalances. 'Overall, it must simply be concluded that the problems of human resource planning are particularly acute in island micro-states' (Connell, 1988a: 23). Pitcairn Island is the extreme scenario of a territory risking depopulation (Connell, 1988b).

Many small islanders from sub-national jurisdictions look upon citizenship rights as a double privilege: it is a condition which grants the basis for property ownership and employment on their own island, while providing them with a passport for potential emigration and freedom of access to the territory and labour markets of the same metropolitan power. The citizens of the UK's overseas territories have enjoyed free access to the UK since 1999 (a right hitherto extended only to the citizens of the Falkland Islands and Gibraltar); the citizens of Puerto Rico enjoy free access to the USA; Lisbon granted citizenship rights in Portugal to almost all citizens of Macau before the transfer of that territory to China in 1999. Island autonomies with a special association with New Zealand Cook Islands, Niue, Tokelau - had half of their island-born population living in New Zealand by the mid-1980s (Bertram, 1986). Indeed, 'unconstrained migration' to a mother country - typically the former colonial power - is one key benefit of negotiating self-determination without independence for small island territories (Connell, 1988a: 12).

But migration policy extends to non-locals, too. Concurrently, other island populations have become swollen with the influx of foreigners. In the Balearics, $90 \%$ of the population increase in recent years has been due to immi- 
gration for the purpose of retirement or employment (Conference of Peripheral Maritime Regions, 2002: 67). Territories like Åland, Bermuda and Malta have adopted immigration policies which favour a stream of limited but wealthy immigrants. ${ }^{10}$ Meanwhile, there are downsides: temporary residents (tourists) increase competition for local, scarce resources. Many small islands receive annual visitor numbers which are many times the size of the local population (McElroy, 1998). Temporary or permanent visitor influx acts to raise the price of housing, at times beyond the reach of local islanders, causing political ripples.

\section{Para-diplomacy}

The devolution of representative power to institutions above or below the nation state has taken on some momentum in recent years. Notable among these is the increasing demand for political power by cities and large urban metropoles in a burgeoning knowledge economy. In Europe, the Committee of the Regions within the EU is one such legitimate advisory body. Such 'para-diplomacy' has involved subnational governments setting up offices in Brussels or in other countries, within and outside the EU. A component of such devolution finds expression in the flurry of international activity by sub-national 'authorities'. The Catalan government has been a recent striking example as part of a wider process of recent and ongoing transformation of the EU into a structure of multi-level governance, defying those who, within a sovereigntist mould, had only been able to imagine that the future was a Europe of nation states or a new country called Europe. Another is the Canadian Province of Québec, an active (non-sovereign state) member of the Francophonie. The Riau Islands form the plank of a Singaporean-Indonesian collaborative effort to kickstart development projects by creating jurisdictional enclaves, bolder than the exclusive economic zones of earlier development strategies. 'De facto states' in the international system - like the Turkish Republic of Northern Cyprus or the Tamil-controlled parts of Sri Lanka (Tamil Eilam) - press for recognition on the international stage, seeking to bypass other regimes (Bahcheli et al., 2004). Other proponents of para-diplomacy include Tatarstan in
Russia (Sharafutdinova, 2003), the German Lander, and the Belgian region of Flanders (Aldecoa and Keating, 1999). In the world of island jurisdictions, para-diplomacy is one of the advantages of autonomy without sovereignty.

\section{Discussion}

These five capacities can be seen to form a unified whole, being, like the MIRAB model, the distinct strands of a broad strategy for securing unorthodox economic development: People considerations affecting citizenship, residence and employment rights $(\mathrm{P})$; Resource management (R); Overseas engagement and ultranational recognition (O); Finance $(\mathrm{F})$ and Transportation ( $\mathrm{T})$. The acronym in this case spells PROFT, although assigning two letters to 'Finance' (FI) - just as 'Migration' is assigned two letters (MI) in the MIRAB name - would spell an actual word, and would be arguably easier to remember than MIRAB: PROFIT (Table 1).

PROFIT economies would therefore differ from their MIRAB neighbours by being more interested in: a shrewd immigration and cyclical migration policy; engaging in tough external negotiations concerning the use of local mineral, natural, political and other imaginative resources; securing and controlling viable means of transportation; and luring foreign direct investment via very low/no tax regimes.

Table 1. Characteristics of MIRAB and PROFIT economies

\begin{tabular}{ll}
\hline MIRAB economies & PROFIT economies \\
\hline Migration (out) & Migration (in/out) \\
Remittances (high) & Remittances (low/medium) \\
Aid (high) & Aid (low/nil) \\
Bureaucracy (high) & Bureaucracy (medium/high) \\
Resource management & Resource management \\
$\quad$ (low/nil) & (medium/high) \\
(Para-)Diplomacy (subsidy- & (Para-)Diplomacy \\
driven) & (procedure-driven) \\
Finance management (low) & Finance management \\
& (medium/high) \\
Transportation & Transportation management \\
management (low) & (medium/high) \\
Manufactures (low) & Manufactures (medium) \\
\hline
\end{tabular}


Rather than assume that the MIRAB model is the fundamental destiny of small economies, and that any departures from it constitute exceptions or periods of dormancy, I would rather conceptualise the state of affairs as a dynamic continuum with two extreme positions, MIRAB representing one of these extremes:

\section{MIRAB}

PROFIT

To what extent are the MIRAB and the PROFIT syndromes similar and different? Can, and if so, how, does an island community graduate away from one syndrome towards the other? Is tourism one of the devices to escape the MIRAB mould?

Certainly, both MIRAB and PROFIT models constitute approaches towards managing the hinterland beyond via primarily non-agricultural, non-manufacturing, non-industrialisation and non-commodity production strategies. Both MIRAB and PROFIT economies are likely to exhibit 'bureaucratic dominance' (Watters, 1987: 50) given structural diseconomies of scale. Both are likely to depend substantially on 'rent income' which accrues by virtue of identity and location (Bertram and Watters, 1985: 510). But one approach can ride piggy back on the other: in effect, a successful proactive production strategy for small island economies lies in the 'marketing of identity' (Fairbairn, 1988: 75; Baldacchino, 1999, 2002) for what are typically more expensive, craft-based, lowertechnology manufactures.

Second, the contrast between some features of the two models can be construed as differences of degree rather than kind. When it comes to remittances, migration or a bureaucracy, clearly all contemporary societies are going to have elements of all three at any time; and so the dependence on any of these three sectors for economic purposes becomes a relativistic one.

Third, one key difference between MIRAB and PROFIT lies in the priority given to substantive as against procedural interests. The first when successful - is an end in itself, the second is a means to a further end. The first relegates the MIRAB territory to a regime of subsidy, of aid with dignity, of consumer-led growth with- out development, of seeking the responsibility for economic benefits in exogenous, extraterritorial policy fora. The second - when successful - is a jurisdictional or constitutional tool, an endogenous instrument for public policy which local 'governing wits' (Warrington, 1998: 105) can usually transform into economic prosperity. Attitude matters.

Fourth, it is possible for features of the MIRAB and PROFIT economies to coexist. Indeed, at any point in time, most economies are likely to exhibit elements of both dispositions, especially if they both prove to be responses to windows of opportunity. Where choices are and can be made between one strategy and another, then, just like other economic decisions, the disposition to seek one road to largesse rather than another would depend largely on opportunity costs, track records of success, lower perceived effort, lower perceived risk, or higher perceived gain, just like any standard utility curve transaction.

Fifth, it is practical to assume that, at a number of points in time, an economy may undergo a lurch from a MIRAB towards a PROFIT society, or vice versa. The collapse of civil law and governance structures in the Solomon Islands, the exhaustion of the phospate mines and the mismanagement of their previous accumulated revenue in Nauru, the landfall of a hurricane or any other major environmental disaster - such occasions are likely to nudge small economies, steadily or suddenly, along the MIRAB path, for better or for worse, for a temporary period or an interminably long one. The opposite lurch is also likely. Watters (1987: 33) is self-critical enough to identify what he calls 'exceptions' to the MIRAB pattern among the five prototype island economies which were documented in the pioneering 1985 article: the temporary citrus boom and the stimulus of a state-promoted cannery in the Cook Islands; the high-level export of phosphates until their exhaustion in 1979 in Kiribati.

Meanwhile, pearl-farming in French Polynesia appeared to be reducing dependence on 'geo-strategic rents' and shifting its economy towards a PROFIT direction (Poirine, 1998: 97); aid per capita had fallen by more than $50 \%$ in real terms between 1992 and 1997 (Poirine, 1998). Even on small and remote Pitcairn, a historic decision appears to have been taken to allow a consortium to build a tourist resort plus 
fish processing plant on the main island. ${ }^{11}$ In spite of powerful vested interests of entrenched politico-economic elites, one can contemplate a 'post-MIRAB economy' (Treadgold, 1999: 236), as also suggested for Guam and Hawaii (Poirine, 1998).

Sixth, one needs to appraise the impact of tourism on both MIRAB and PROFIT economies. Tourism comes along with 'genuine comparative advantages' for island microstates (Connell, 1991: 265). Treadgold (1999) has argued that tourism has helped to break Norfolk Island, a previously classic MIRAB case, out of this structural mould. Tourism has now 'erased' Norfolk island's MIRAB characteristics or rendered them insignificant, it is claimed. However, tourism is in itself a rent-accruing activity bearing its own 'geo-strategic' (that is sun, sea, salt, sand - and sex?) services which hardly vest jurisdictional muscle to the provider; the industry remains fickle and vulnerable, mainly to economic uncertainty and both local and regional political instability. It is also a largely private sector activity lying outside of 'managed' external relationship syndromes. Or is it? Perhaps tourism can be seen as part of a 'hinterland management' system if it is driven by special concessions from metropolitan powers or else benefits handsomely from tourists from the same metropolitan sites. ${ }^{12}$

Seventh, it would be useful to find quantitative indicators which correspond to the PROFIT syndrome, much like the visually evocative analysis of the 'jaws effect' (imports outpacing exports; expenditure outpacing revenue) (Bertram and Watters, 1985: 510) for the MIRAB model. Perhaps, as with the Bertram and Watters' pioneering research of 20 years ago, one needs to identify a clutch of PROFIT economies - some sovereign states, some sub-national autonomous units - and soberly analyse their economic statistics, migratory patterns, public sector financial health and, in the outcome, seek to distil some comparative patterns. Likely candidates for this exercise would include Åland, Aruba, Bermuda, Cyprus, Iceland, Malta and Seychelles.

\section{Conclusion: Merodia}

The archipelago of Merodia, population 200000 , is a region of the republic of Lagado, a member state of the enlarged European
Union. ... (Conference of Peripheral Maritime Regions, 2002)

It would only be an act of historical continuity to resort to imaginary islands for didactic purposes. Jonathan Swift created Lilliput to satirise British high society; Daniel Defoe invented Robinson Crusoe and his island to present an account of the development of capitalism (Hymer, 1971); Jules Verne's Mysterious Island demonstrates humankind's superiority over nature in the epoch of industrialism (Loxley, 1990); the island in Shakespeare's The Tempest is the setting for the critique of ethnicity and colonialism (Brinklow et al., 2000).

The smaller the territory and the smaller the resident population, the more likely is it for that territory and that population to rely on external inputs for sheer survival. The fictitious Merodia is one recent attempt at mulling and moralising over the role of external support for island development. It seeks to demonstrate how a 'European islands policy combining understanding, flexibility and solidarity with regard to these [that is, island] regions leads to their full integration within the [European] Union' (Conference of Peripheral Maritime Regions, 2002: 129). Furthermore, the implications of such a policy would '... affect Europe as a whole' (Conference of Peripheral Maritime Regions, 2002). Merodia becomes the contemporary experiment - and whether the outcome is a utopia or dystopia is seen to depend on 'managing the hinterland'. The 'permanent and pervasive realities' of islands call for differential treatment (Conference of Peripheral Maritime Regions, 2002). The MIRAB syndrome, as much a series of economic transactions as an 'in-itsown-way' sustainable cultural lifestyle, is certainly one response towards the recognition of this special handling.

But there are other responses beyond MIRAB. Size of land area, population levels, regional location or political status do not appear to preempt the consideration of non-MIRAB options, and allow for even messier 'mix and match' approaches. That is why the MIRAB model, the PROFIT model, or any other model for that matter is best seen as an abstract, ideal type: seductively elegant in its conceptual simplicity, but not present in its pure form anywhere in the real world (after Weber, 1949: 89-95). 


\section{Acknowledgements}

The support of the Social Sciences \& Humanities Research Council of Canada (SSHRC) via the allocation of a Standard Research Grant 'Patterns of Sub-National Autonomy among the World's Islands' (SRG No: 410-2004-0397) is gratefully acknowledged. My thanks to Harvey Armstrong, Jerome McElroy, Robert Read, Paul Streeten and Geoffrey Wall and anonymous referees for critical comments, constructive criticism and helpful research leads.

\section{Notes}

1 See also: http://www.cru.uea.ac.uk/cru/tiempo/ issue10/characts.htm (Accessed 31 July 2004).

2 A case in point: The inhabitants of Prince Edward Island often complain because theirs is the most densely populated province in Canada - with just 24 persons per square kilometre!

3 A search for the keywords 'MIRAB' and 'Island' using Google search engine landed 442 hits on 5 December 2003 and 466 hits on 8 February 2004.

4 A case in point: Developing Batam Island as an exclusive economic zone within Indonesia, exploiting its proximity to Singapore, was a unilateral decision of Jakarta and intensified the powerlessness of the Batanese. See (Royle, 1997).

5 In the run-up to eventual independence, both Malta and Mauritius first sought integration with Britain.

6 Http://www. lowtax.net (Accessed 31 July 2004).

7 Such cases include: the issue of oil and gas reserves in the discussions over the potential secession of the Faroe Islands from the Danish realm, as well as on the status of the Falkland Islands (because of oil); the granting by Westminster of special tax-raising powers related to North Sea oil/gas to the Shetland Islands; the British Virgin Islands and Bermuda (because of offshore banking) under the British Crown; India's relationship with the Andaman and Nicobar Islands - seen as having strong tourism potential; the use of Kwalajein Atoll by the US Military within a Compact of Free Association between the Marshall Islands and the USA. The cultivation of political loyalty explains most of Gozo's administrative autonomy within the Maltese state. Cullen (1990) explores the different ways in which Australia and Canada handled the management of natural resources within their sub-national jurisdictions.

8 I am grateful to lain Orr for this information (e-mail communication dated 19 September 2003).

9 The UNESCO World Heritage List is available at: http://whc.unesco.org/heritage.htm (Accessed 31 July 2004).

10 For example, foreigners in Bermuda are more or less unable to buy land or property, other than houses with an annual rental value in excess of US\$43 800, equivalent to a sale price of US\$500 000 approx. Currently, only 312 houses qualify. Visit: http://www.lowtax.net/ lowtax/html/bermuda/jbrres.html (Accessed 31 July
2004). In 2002, Malta successfully negotiated a landmark permanent derogation with the European Commission preventing non-Maltese, non-resident EU citizens from buying property in Malta (The Economist, 2004). Prevention of purchase of property by nonÅlanders in Åland is also a safeguard in Finland's Treaty of Accession to the EU in 1995.

$11 \mathrm{Http}: / / w w w . a g e o f c o n s e n t . c o m / p i t c a i r n . h t m$ (Accessed 31 July 2004).

12 I wish to thank Harvey Armstrong for these insights. He has suggested the acronym PROFITT, the second ' $\mathrm{T}$ ' standing for Tourism. Private communication, dated 3 March 2004. While I am honoured that the PROFIT acronym is already inviting hybrids (as MIRAB has been doing), this specific matter is one that calls for further research.

\section{References}

Abbott, J. (2000) Treasure island or desert island? Offshore finance and development in Labuan, Development Policy Review 18(2): 157-175.

Aldecoa, F. and M. Keating (eds.) (1999) Paradiplomacy in action. The external activities of sub-national governments. London: Frank Cass.

Armstrong, H.W. and R. Read (1998) The international political economy of micro-states: An overview, paper presented at Islands of the World V Conference, Mauritius, University of Mauritius, July.

Armstrong, H.W. and R. Read (2002) The phantom of liberty? Economic growth and the vulnerability of small states, Journal of International Development 14(3): 435-458.

Bahcheli, T., B. Bartmann and H.F. Srebrnik (eds.) (2004) De facto states: The quest for sovereignty. London: Taylor \& Francis.

Baldacchino, G. (1993) Bursting the bubble: The pseudodevelopment strategies of microstates, Development and Change 24(1): 29-51.

Baldacchino, G. (1997) Global tourism \& informal labour relations: The small scale syndrome at work. London: Mansell.

Baldacchino, G. (1998) The other way round: Manufacturing as an extension of services in small states, Asia Pacific Viewpoint 39(3): 267-279.

Baldacchino, G. (1999) An exceptional success: The case study of an export oriented, locally owned, small scale manufacturing firm in a small island country, Journal of Pacific Studies 23(1): 27-47.

Baldacchino, G. (2000) The challenge of hypothermia: A six-proposition manifesto for small island territories, The Round Table 353: 65-79.

Baldacchino, G. (2002) A taste of small island success: A case from Prince Edward Island, Journal of Small Business Management 40(3): 254-259.

Baldacchino, G. (2004) Sustainable use practices, including tourism, in/for small islands, INSULA: International Journal of Island Affairs 14(1): 5-10.

Baldacchino, G. and D. Fabri (1999) The Malta financial services centre: A study in micro-state dependency management? in M.P. Hampton and J.P. Abbott (eds.), Offshore finance centres and tax havens: The rise of global capital, pp. 140-165. Basingstoke: Macmillan. 
Baldacchino, G. and D. Milne (eds.) (2000) Lessons from the political economy of small islands: The resourcefulness of jurisdiction. New York: St. Martin's Press, in association with Institute of Island Studies, University of Prince Edward Island, Canada.

Bayliss-Smith, T., R. Bedford, H.C. Brookfield and M. Latham (1988) Islands, islanders and the world: The colonial and post-colonial experience in eastern Fiji. Cambridge: Cambridge University Press.

Bell, D. (1987) The world and the United States in 2013, Daedalus 116(1): 1-31.

Bertram, G. (1993) Sustainability, aid and material welfare in the small South Pacific Island economies: 19001990, World Development 21(2): 247-258.

Bertram, G. (1999) The MIRAB model: Twelve years on, The Contemporary Pacific 11(1): 105-138.

Bertram, G. (2004) On the convergence of small island economies with their metropolitan patrons, World Development 32(2): 343-364.

Bertram, G. and R.F. Watters (1985) The MIRAB economy in South Pacific microstates, Pacific Viewpoint 26(3): 497-519.

Bertram, G. and R.F. Watters (1986) The MIRAB process: Earlier analysis in context, Pacific Viewpoint 27(1): 4759.

Blackadder, A. (1998) The case of oil in the Shetland Islands, in G. Baldacchino and R. Greenwood (eds.), Competing strategies of socio-economic development for small islands, pp. 91-118. Charlottetown, Canada: University of Prince Edward Island, Institute of Island Studies.

Briguglio, L. (1995) Small island developing states and their vulnerabilities, World Development 23(9): 1615-1632.

Brinklow, L., F. Ledwell and J. Ledwell (eds.) (2000) Message in a bottle: The literature of small islands. Charlottetown, Canada: University of Prince Edward Island, Institute of Island Studies.

Brookfield, H.C. (1986) An approach to islands, Interoceanic Workshop on Sustainable Development and Environmental Management of Small Islands, Puerto Rico.

Caldwell, J.C., G.E. Harrison and P. Quiggin (1980) The demography of micro-states, World Development 8(12): 953-967.

Chongyi, F. and D.S.G. Goodman (1997) Hainan: Communal politics and the struggle for identity, in D.S.G. Goodman (ed.), China's provinces in reform, pp. 5380. London: Routledge.

Christensen, J. and M.P. Hampton (1999) A legislature for hire: The capture of the state in Jersey's offshore finance centre, in M.P. Hampton and J.P. Abbott (eds.), Offshore finance centres and tax havens: The rise of global capital, pp. 166-191. Basingstoke: Macmillan.

Conference of Peripheral Maritime Regions (CPMR) (2002). Off the coast of Europe: European construction and the problem of the islands. Saint Malo: France, study undertaken by Eurlsles on the initiative of CPMR.

Connell, J. (1988a) Sovereignty and survival: Island microstates in the Third World, Research Monograph No. 3. Sydney: Department of Geography, University of Sydney.
Connell, J. (1988b) The end ever nigh: Contemporary population change on Pitcairn Island, Geojournal 6: 193-200.

Connell, J. (1991) Island microstates: The mirage of development, The Contemporary Pacific 3(2): 251-287.

Connell, J. and R. Aldrich (1992) France's overseas frontier. Cambridge: Cambridge University Press.

Courchene, T.J. (1995) Globalisation: The regional/international interface, Canadian Journal of Regional Science 18(1): 1-20.

Cracknell, B. (1967) Accessibility to the countryside as a factor in planning for leisure, Regional Studies 1(1): 147-161.

Cullen, R. (1990) Federalism in action. NSW, Australia: Federalist Press.

Dommen, E.C. (1980) Some distinguishing characteristics of island states, World Development 8(12): 931-944.

Doumenge, F. (1989) Basic criteria for estimating the viability of small island states, in J. Kaminarides, L. Briguglio and H.N. Hoogendonk (eds.), The economic development of small countries: Problems, strategies and policies, pp. 37-56. Delft, The Netherlands: Eburon.

Easterly, W. and A. Kraay (2000) Small states, small problems? Income, growth and volatility in small states, World Development 28(11): 2013-2027.

Fairbairn, T.I.J. (1988) Indigenous entrepreneurship \& business development in the Cook Islands, in T.I.J. Fairbairn (ed.), Island entrepreneurs: Problems and performance in the South Pacific, pp. 55-76. Honolulu: East-West Center.

Fleming, E. (2002) Strategic paths to competitiveness in agriculture in South Pacific Island Nations, UNCTAD paper. Accessed 31 July 2004, available at: http://rO.unctad.org/infocomm/diversification/nadi/ study_ver2.PDF

Fox, A. (1969) A sociology of work in industry. London: Collier-Macmillan.

G7 Financial Action Task Force on Money-Laundering (2000) Review to Identify Non-cooperative Countries or Territories: Increasing the World's Effectiveness of Anti-money Laundering Measures. Paris, June.

Gössling, S., C. Borgström Hansson, O. Hörstmeier and S. Saggel (2002) Ecological footprint analysis as a tool to assess tourism sustainability, Ecological Economics 43(2): 199-211.

Green, W.A. (1984) The perils of comparative history: Belize and the British sugar colonies after slavery. Comparative Studies in Society of and History 26(1): 112-119.

Greer, T. and G. Wall (1982) Recreational hinterlands: A theoretical and empirical analysis, in G. Wall (ed.), Recreational land use in Southern Ontario, Publication Series No. 14. Waterloo: Department of Geography, University of Waterloo.

Griffith, V. and M. Inniss (1992) Environmental diplomacy: An effective tool for small island states to define a more dynamic role in international environmentaldevelopment negotiations, Bulletin of Eastern Caribbean Affairs 17(1-2): 43-54.

Guillebaud, J.C. (1976) Les confettis de IEmpire. Paris: Seuil. 
Guthunz, U. and F. von Krosigk (1996) Tourism in small island states: From Mirab to Tourab? in L. Briguglio, B. Archer, J. Jafari and G. Wall (eds.), Sustainable tourism in islands and small states: Issues and policies, pp. 1835. London: Pinter.

Hamilton-Jones, D. (1992) Problems of inter-island shipping in archipelagic small-island countries: Fiji and the cook islands, in H.M. Hintjens and M.D. Newitt (eds.), The political economy of small tropical islands: The importance of being small, pp. 200-222. Exeter: University of Exeter Press.

Hampton, M.P. (1994) Treasure islands or fools gold: Can and should small island economies copy jersey? World Development 22(2): 237-250.

Hampton, M.P. and J.P. Abbott (1999b) The rise (and fall?) of offshore finance in the global economy: Editors' introduction, in M.P. Hampton and J.P. Abbott (eds.), Offshore finance centres and tax havens: The rise of global capital, pp. 1-17. Basingstoke: Macmillan.

Hintjens, H.M. (1991) France in the Caribbean, in P. Sutton (ed.), Europe and the Caribbean, pp. 37-70. London: Macmillan.

Houbert, J. (1986) France in the Indian ocean: Decolonizing without disengaging, The Round Table 298: 145-166.

Hymer, S. (1971/2) Robinson Crusoe and the secret of primitive accumulation, Monthly Review 23(1): 1026.

Kakazu, H. (1994) Sustainable development of small island economies. Boulder, Colorado: Westview Press.

Lindström, B. (2000) Culture and economic development in Åland, in G. Baldacchino and D. Milne (eds.), Lessons from the political economy of small islands: The resourcefulness of jurisdiction, pp. 107-121. New York: St. Martin's Press, in association with Institute of Island Studies, University of Prince Edward Island, Canada.

Loxley, D. (1990) Problematic shores: The literature of islands. Basingstoke: Macmillan.

Marcus, G. (1981) Power on the extreme periphery: The perspective of Tongan elites in the modern world system, Pacific Viewpoint 22(1): 48-64.

McElroy, J.L. (1998) A propensity for dependence, Islander (UK, Habitat Scotland) 5: 33.

McElroy, J.L. and L. Morris (2002) African island development experiences: A cluster of models, Bank of Valletta review, Malta 26: 38-57.

McElroy, J.L. and M. Mahoney (1999) The propensity for political dependence in island microstates, INSULA: International Journal of Island Affairs 9(1): 32-35.

McKercher, W.R. (2000) The isle of man: Jurisdictional catapult to development, in G. Baldacchino and D. Milne (eds.), Lessons from the political economy of small islands: The resourcefulness of jurisdiction, pp. 91-106. New York: St. Martin's Press, in association with Institute of Island Studies, University of Prince Edward Island, Canada.

Miles, W.F.S. (1986) Elections and ethnicity in French Martinique: Paradox in paradise. New York: Praeger.

Milne, D. (2000) Ten lessons for economic development in small jurisdictions: The European perspective. Charlot- tetown: Institute of Island Studies, University of Prince Edward Island.

Milne, S. (1992) Tourism development in Niue, Annals of Tourism Research 19(3): 565-569.

Munro, D. (1990) Transnational corporations of kin and the MIRAB system, Pacific Viewpoint 31(1): 63-66.

Ogden, R.M. (1993) Locating technology in the development debate: From MIRAB to MIRTAB. in Islands on the net: Technology and development futures in pacific island microstates, Chapter 6, unpublished PhD Dissertation. Honolulu: Department of Political Science, University of Hawaii.

Olafsson, Á. (2000) Constitutionalism and economics in the Faroes, in G. Baldacchino and D. Milne (eds.), Lessons from the political economy of small islands: The resourcefulness of jurisdiction, pp. 121-140. New York: St. Martin's Press, in association with Institute of Island Studies, University of Prince Edward Island, Canada.

Poirine, B. (1998) Should we hate or love MIRAB? The Contemporary Pacific 10(1): 65-106.

Prasad, N. (2004) Escaping regulation, escaping convention: Development strategies in small economies, World Economics 5(1): 41-65.

Rosenau, J.N. (2003) Distant proximities: Dynamics beyond globalization. Princeton, New Jersey: Princeton University Press.

Royle, S.A. (1989) A human geography of islands, Geography 74(1): 106-116.

Royle, S.A. (1997) The benefits of insularity on development: The case of Batan Island, Indonesia, paper presented to Development Studies Association Conference. Norwich: University of East Anglia, September.

Royle, S.A. (2001) A geography of islands: Small island insularity. London: Routledge.

Royle, S.A. and D. Scott (1996) Accessibility and the Irish Islands, Geography 81(2): 111-119.

Sharafutdinova, G. (2003) Paradiplomacy in the Russian regions: Tatarstans search for statehood, Europe-Asia Studies 55(4): 613-629.

Streeten, P.P. (1993) The special problems of small countries, World Development 21(2): 197-202.

Sutton, P. (1987) Political aspects, in C.G. Clarke and T. Payne (eds.), Politics, security \& development in small states, pp. 3-25. London: Allen \& Unwin.

The Economist (2003) On the world's rich list. London: The Economist Magazine, May 17, p. 33.

The Economist (2004) Smallness pays. London: The Economist Magazine, February 26. Accessed 31 July 2004, available at: http://www.economist.com/ displayStory.cfm?story ID $=2461814$

Treadgold, M.L. (1999) Breaking out of the MIRAB mould: Historical evidence from Norfolk Island, Asia Pacific Viewpoint 40(3): 235-249.

Trompf, G. (ed.) (1993) Islands and enclaves: Nationalisms and separatist pressures in island and littoral contexts new. Delhi: Sterling Publishers.

Warrington, E. (1998) Introduction: Gulliver and Lilliput in a new world order: The impact of external relations on the domestic policies and institutions of micro- 
states, Public Administration and Development 18(2): 101-105.

Watters, R.F. (1987) Mirab societies and bureaucratic elites, in A. Hooper (ed.), Class and culture in the South Pacific, pp. 32-55. Suva: Institute of Pacific Studies.

Watts, R.L. (2000) Islands in comparative constitutional perspective. in G. Baldacchino and D. Milne (eds.), Lessons from the political economy of small islands: The resourcefulness of jurisdiction, pp. 17-37. New
York: St. Martin's Press, in association with Institute of Island Studies, University of Prince Edward Island, Canada.

Weber, M. (1949) The methodology of the social sciences, translated by E. Schils and H. Finch. New York: The Free Press.

Winchester, S. (1985) Outposts: Journeys to the surviving relics of the British empire. Seven Oaks: Sceptre Books. Young, L.B. (1999) Islands: Portraits of miniature worlds. New York: W.H. Freeman \& Co. 